\title{
The Economic Impact of Covid-19 Pandemic on Female Workers in Serang City, Banten
}

\author{
Wahyu Kartiko Utami ${ }^{*}$, Nikki Prafitri² \\ 1,2Department of Goverment Studies, Faculty of Social and Political Sciences, Universitas Sultan \\ Ageng Tirtayasa \\ Jl. Raya Jakarta KM. 04 Pakupatan, Serang, Banten, Indonesia, 42118 \\ *Corresponding author:wahyu.kartiko@untirta.ac.id
}

\begin{abstract}
This research discusses the Covid-19 pandemic and its impact on the of female workers economy in Serang City. The Covid-19 pandemic has affected various areas of people's life, including the economy. On the other hand, female workers are among those affected by Covid-19. The theory used in this study is the Cohen economic impact theory which includes the impact on income, the impact on economic activity and the impact on expenditure. The research method used is qualitative research with a qualitative descriptive approach. Data collection techniques using observation, in-depth interviews and documentation. This research's informants are the Labor Office of Serang Banten, the Giant Labor Community, and formal female workers. The results showed that the Covid-19 pandemic in Serang City influenced some female workers' economic aspects, such as income, economic activities, and expenditure. This influence is especially for women workers affected, such as female workers at home, who are laid off until their work contract is terminated.
\end{abstract}

Article Info :

\section{INTRODUCTION}

Currently, Indonesia and the world are facing a coronavirus pandemic, also known as Covid-19. The virus that infects the respiratory system has spread across the globe, including Indonesia. Furthermore, Covid-19 causes the common cold to more severe illnesses such as Middle East Respiratory Syndrome (MERS-Cov) and Severe Acute Respiratory Syndrome (SARS-Cov).

Indonesia is one of the countries which has been affected by Covid-19. Covid19 was already detected for the first time since March 2020 but has spread to various regions in Indonesia. The spread of this virus begins with a slow government response and anti-scientific behavior that does not make the Indonesian government understand the context of Covid-19 as a deadly epidemic (Agustina \& Octaviani, 2017). This weak 
response in handling Covid-19 was also supported by low community readiness and adherence to health protocols during the pandemic. The Indonesian government also chose not to implement a lockdown policy to prevent the spread of Covid-19. The government's reason is that the lockdown policy will harm the people's economy. However, with these various efforts and phenomena, the Covid-19 cases in Indonesia are still increasing.

Covid-19 first occurred in Wuhan in December 2019. This virus has a risk of death for sufferers. Of the 251 Covid-19 patients in Wuhan who were included in a study, the mortality rate could reach $3.77 \%$. The risk of death often occurs in the elderly and patients with chronic diseases (Zhang et al., 2020). Indonesia was also severely affected by Covid-19, where the death rate reached 8.9\% at the end of March 2020. The government needs to take significant steps by limiting people from leaving their homes and improving health services (Setiati \& Azwar, 2020). The high mortality rate and the spread of the virus that is still occurring are due to Indonesia's delay in responding to the health crisis during the outbreak of Covid-19, spread in neighboring countries in January-February 2020. This condition has harmed public health in Indonesia (Olivia, Gibson, \& Nasrudin, 2020).

The spread of Covid-19, which has spread widely to various parts of the world, has impacted multiple aspects, where health aspects are affected and characteristic of the Indonesian economy, such as trade and tourism to investment. The social aspect is inseparable from Covid-19, where all the world, including Indonesia, have been affected by the prohibition of gathering or grouping. The ban carried out by many countries in the world is also called social distancing and physical distancing, which is keeping a distance from each other. Maintaining this distance is one of the government's efforts and the community to break the covid-19 virus chain's spread. Besides, maintaining this distance is also the key to stopping the outbreak of this deadly virus.

The economic sector has become one of the most affected sectors since the existence of Covid-19. The economy is one of the critical factors in human life, wherein everyday life humans always intersect with economic needs (Hanoatubun, 2020). The emergence of Covid-19, which infected China, brought China's trade activities in a negative direction so that it impacted the flow and world trade system so that it also had an impact on Indonesia (Nasution, Erlina, \& Muda, 2020). The effect of COVID-19 not only disrupts Indonesia's export and import sectors but also attacks the trade sector, especially from decreased tax revenue. This situation has a severe impact because, in the trade sector, tax revenue has an enormous contribution in boosting state revenue, to be precise, which is in the second largest position (Sugarda \& Wicaksono, 2017).

The tourism sector is also one of the scorers that have not been affected by Covid-19, based on data compiled from the Central Bureau of Statistics. It is explained that in 2019 Chinese travellers who came to Indonesia touched the number of 2.07 million tourists or around $12.8 \%$ of the total number of foreign tourists throughout 2019. The COVID-19 pandemic has resulted in a decline in tourists coming to Indonesia. Supporting sectors for tourism, namely restaurants, hotels and retailers, have also been affected by the COVID-19 pandemic. Hotel profits have decreased by up to $40 \%$, impacting hotel operations and threatening its business continuity. The decline in

14| Journal of Local Government Issues (Logos), 4 (1), March 2021, pp 13- 29 ISSN : $2620-8091$ print | 2620-3812 online 
foreign visitors also affects restaurants' income or restaurants with dominant foreign customers (Block, 2017).

Weak tourism growth also has an impact on the retail industry. Furthermore, the tourism sector's sluggishness has a domino effect on the Micro, Small and Medium Enterprises (MSMEs) sector (Bahtiar \& Saragih, 2020). If foreign visitors who visit decline, it is inevitable that income from micro, small and medium enterprises will also decrease (Saidi et al., 2017). Bank Indonesia has released data in 2016 related to the micro, small, and medium business sectors, stating that micro, small, and medium enterprises are very dominant in Indonesia's business units. The type of micro business can absorb many workforces.

The dilemma of various countries in overcoming Covid-19 makes the government and even the public feel anxious and lost, impacting health and the economy (Juaningsih, 2020). This issue then led the Indonesian government to issue a policy regulated in PP. 21 of 2020 concerning PSBB (Large-Scale Social Restrictions) to break the chain of spreading Covid-19. This policy has led several companies to reduce losses due to Covid-19, where one of the steps taken by several companies in Indonesia is to terminate employment (PHK) for employees working at the company. This decision is in line with Articles 164 and 165 of Law No. 13 of 2003 (Indonesia, 2003) concerning Manpower. More or less, the phrase states that a company has the right to terminate employment relations with employees if a company experiences a loss.

Amid the Covid 19 pandemic, employment problems have become a specific issue that arises with deaths. There are many cases where workers have to be at home until they are terminated. It has happened in almost all parts of Indonesia, even in other countries such as the United States, Germany, Spain, China, etc. As Indonesia's data for workers laid off and subjected to layoffs, more than 1.5 million. Many as 1.24 million people are formal workers, and 265 thousand are informal workers (Hanoatubun, 2020). It is unfortunate, considering that the community is faced with the danger of death due to Covid 19 and hunger due to losing jobs that support them and their families.

Instead of imposing a lockdown on the assumption that people's economic activities will continue to run well, the government has chosen to implement the largescale social restrictions policy. The large-scale social restriction has been selected as a policy that is considered to have a small risk of economic impact during the pandemic. However, this is different from the results of the research. (Suryahadi, Al Izzati, \& Suryadarma, 2020) show that the economic impact of Covid-19 in Indonesia is expected to be very significant. The projection of economic growth will collapse to between $4.2 \%$ and $-4.7 \%$ in 2020 . The poverty rate will increase from $9.2 \%$ to $9.7 \%$ in 2020 . This poverty is partly affected by people who lose their jobs due to limited companies, the low purchasing power of people for products, difficulties in obtaining input materials, and poor ability to pay creditors. The pandemic also caused a recession that resulted in reduced labor supply due to restrictions, businesses that depend on social gatherings and physical presence to a halt, reduced labor-intensive manufacturing, and informal workers who relyon labor market mobility also lost their jobs (Olivia et al., 2020).

Female workers have a higher burden than male workers, especially female workers who are married and have children. After completing their work, they must

15| Journal of Local Government Issues (Logos), 4 (1), March 2021, pp 13- 29 ISSN : 2620-8091 print | 2620-3812 online 
change to their domestic roles as wives and homemakers who still have to take care of their husbands or children. Even in the world of work, women face many obstacles when compared to male workers. The female labor force, whichis pregnant to breastfeeding and caring for children, makes the workforce burden for women unbalanced so that not a few women whose careers are not as bright as men's where they have to stop due to their domestic role housewives. The Covid-19 pandemic is also one of the obstacles that add to the burden on working women. According to UN Women's latest global data, the coronavirus pandemic can erase 25 years of struggle in creating gender equality (BBCNews, 2020). She added, based on these data, women do more housework and take care of their families due to the impact of covid-19 (BBCNews, 2020).

Besides, opportunities to gain access to work and education may be lost, and women may suffer worse mental and physical health. The burdens of caring and nurturing pose "a real risk of returning to 1950s gender stereotypes", said UN Women Deputy Executive Director Anita Bhatia. Even before the pandemic, women undertook about three-quarters of the 16 billion hours of unpaid work worldwide each day. In other words, for every hour of unpaid work done by men, three hours by women. Now that figure is much higher (BBCNews, 2020).

Serang City is one of Banten Province areas that is not immune from the impact of the spread of Covid-19. Covid-19 causes public health problems, but the community's economy, especially the workforce in Serang City, is also disrupted. As the capital city of Banten Province, Serang City has a reasonably high workforce, wherein 2020 there were 40,061 workers, with a distribution of 33,146 male workers and 6,915 female workers (Office, 2020b).

The presence of Covid-19 has a tremendous and significant impact on various aspects. In terms of health and from an economic factor, it cannot be separated from the effects of the Covid-19 pandemic. Although Serang City is not associated with the number of Covid-19 cases than other districts and cities in Banten, Serang City is mainly affected by its impact on the economy, especially for female workers in Serang City. The City of Serang also carries out the PSBB, so all workers' activities must be sent home. For this reason, this study will examine the impact of corona on the economy of female workers in Serang City. The following is a table of total cases confirmed by Covid-19 in September per district/city in Banten Province, sourced from the Banten Provincial Health Office.

Table 1. Total Confirmed Cases of Covid-19 Per Regency / City in Banten Province

\begin{tabular}{|l|l|l|l|l|l|}
\hline & Total & & Treatment & Recovered & Death \\
\hline Regency/City & & $\mathbf{1 . 2 6}$ & $\mathbf{3 0 8}$ & $\mathbf{9 0 0}$ & $\mathbf{5 7}$ \\
\hline Tangerang City & $\mathbf{5}$ & & & & \\
\hline South Tangerang City & & $\mathbf{1 . 0 0}$ & $\mathbf{1 3 6}$ & $\mathbf{8 1 2}$ & $\mathbf{5 3}$ \\
\hline
\end{tabular}

16| Journal of Local Government Issues (Logos), 4 (1), March 2021, pp 13- 29 ISSN : 2620-8091 print | 2620-3812 online 


\begin{tabular}{|c|c|c|c|c|}
\hline Tangerang Regency & $\begin{array}{ll} & 1.11 \\
4 & \end{array}$ & 514 & 574 & 26 \\
\hline Cilegon City & 365 & 173 & 182 & 10 \\
\hline Serang City & 157 & 68 & 84 & 5 \\
\hline Serang Regency & 197 & 75 & 117 & 5 \\
\hline Lebak Regency & 136 & 79 & 53 & 4 \\
\hline PandeglangRegecny & 91 & 52 & 34 & 5 \\
\hline
\end{tabular}

Source: (Banten Province, 2020)

From the data above, it can be seen that Serang City has a total of 157 confirmed cases of Covid-19 as of September 24, 2020. The most confirmed cases in Banten Province were in the City of Tanggerang with 1,265 cases, while the fewest confirmed cases were in Banten Regency in Pandeglang Regency with 91 cases. If we look at the confirmed cases of Covid-19 in Serang City from March to September 2020, it is fluctuated both from treated patients, recovered patients and patients who died.

Serang City government has the courage not to impose large-scale social restrictions. However, based on data from the Banten Provincial Health Office, Until September 2020, Serang City was surrounded by other cities in its vicinity, such as Cilegon City, South Tangerang City, and Serang Regency, which were once in the Covid19 red zone. The Serang City Government's efforts not to impose large-scale social restriction policies until September 2020 because they consider the Covid-19 cases are not high enough in their area and reduce the economic impact due to restrictions.

The policy of the PSBB has had a significant impact on the community's economic activities in some areas. Thus, the Serang City local government's decision not to implement the PSBB policy even though it is included in the orange zone for the Covid-19 case until September 2020 is considered a step towards saving the community economy in the face of the threat of the Covid-19 case. Within the hope that the economic activities of the community will remain stable. However, although the PSBB did not apply, workers in Serang City were laid off, and trade and retail business activities were also affected. Women's labor is one of those affected.

Since taking place in early 2020 until now, several studies have explained the impact of Covid-19 on the world economy. (Pradana, Wulandari, Noorwidhi, \& Sitinjak, 2020);(Yamali \& Putri, 2020) found data on how complex the Indonesian economy was due to social restrictions that impacted the service and tourism sector. Local economic instability is also due to decreased income from the export sector (Rusiadi, Aprilia, Adianti, \& Verawati, 2020). The regional economy has also experienced a deep slowdown in East Java (Ulya, 2020). In the Regencies of West Lombok (Budastra, 2020) and West Nusa Tenggara (NTB) (Sayuti \& Hidayati, 2020) tourism and transportation as one of the main sectors of people's economic activities have experienced a sluggishness 
so that people's income has decreased drastically. As the primary sector in absorbing employment opportunities, MSMEs also experience a slowdown due to obstruction of product absorption, availability of raw materials, and distribution processes (Bahtiar \& Saragih, 2020). It is also similar to the Klaten and Wonogiri markets, reducing turnover (AZIMAH et al., 2020). In the global context, there was a tremendous economic distraction (Kusno, 2020), which damaged the international market (Ashraf, 2020)which resulted in a significant reduction in employment (Chitiga-Mabugu, Henseler, Mabugu, \& Maisonnave, 2020). Unlike previous studies, this study presents a different perspective because it specifically looks at the direct impact of Covid-19 on female workers in Serang City. What is the multi-dimensional impact that women get, considering that they are the family's economy's backbone?

\section{METHOD}

This research uses qualitative research methods with a qualitative descriptive approach. As expressed by Bogdan and Taylor (Moleong \& Surjaman, 1991), qualitative research is a research procedure that produces descriptive data in the form of written or spoken words from people and observed behaviour. The research data obtained from March-December 2020.

This study aims to analyze the economic impact of Covid-19 on female workers in Serang City. The focus of the research is on female workers in Serang City, and the research subjects are limited to formal female workers, both formal female workers who are contract workers and permanent workers to workers who are directly affected, such as workers in home and workers who were laid off due to the Covid-19 pandemic in Serang City. Although informal workers are also part of the impact, researchers limit it to the formal workforce. As previously explained, the Covid-19 pandemic impacted the economy, causing many companies or industries to take policies such as laying off their employees, including in Serang City. This study wants to analyze further the extent of the impact of Covid-19 on female workers affiliated with companies or industries in Serang City, especially in industries that lay off their workers.

Data collection techniques in this study using observation techniques, in-depth interviews and documentation. In the observation technique, researchers analyzed and observed the female workforce's various impacts in dealing with the Covid-19 pandemic in Serang City.

Then the following technique used by researchers in this study is in-depth interviews. The in-depth interview method was carried out many times and took a long time with informants at the research location (Bungin, 2009). In in-depth interviews, researchers conducted interviews with key informants and supporting informants. The key informants here are formal and informal female workers in Serang City. Meanwhile, the researchers' supporting informants were the Serang City Manpower Office and the Giant Labor Community, Serang City. For more details, the following informant data were examined in this study:

18| Journal of Local Government Issues (Logos), 4 (1), March 2021, pp 13- 29 ISSN : 2620-8091 print | 2620-3812 online 
Table 2. Research Informant

\begin{tabular}{|c|c|c|}
\hline No & Name & Position \\
\hline 1 & Syafa'at & $\begin{array}{c}\text { Head Chief of Labor Official } \\
\text { Government of Serang }\end{array}$ \\
\hline 2 & Adi & Labor Union of Giant Serang \\
\hline 3 & Windi & Female worker \\
\hline 4 & Ade & Female worker \\
\hline 5 & Bella & Female worker \\
\hline 6 & Sartijah & Female worker \\
\hline 7 & Eka & Female worker \\
\hline 8 & Sepvi & Female worker \\
\hline 9 & Linda & \\
\hline
\end{tabular}

Sources: Researcher, 2020

The last technique used by researchers in this study is documentation. Documentation is a method of collecting data through literature studies such as archives, records, and documents of an event connected with the object of research. For documentation techniques, researchers carry out documentation which becomes secondary data in this study. Secondary data includes data confirmed Covid-19 in Serang City, data on the number of workers in Serang City, data on the number of workers who were laid off and laid off in Serang City, data on the number of industries that laid off and laying off employees in Serang City, and policies related to employment in Serang City.

\section{RESULTS AND DISCUSSION}

This part consists of the research results, and researchers are discussed. The Covid-19 pandemic in Serang, Banten, has made many changes, both from a social and economic perspective. The social impacts include reducing the number of employees either through being laid off. It causes other problems such as increased unemployment, considering that their companies have laid off many men and women workers. The Covid-19 pandemic has also made it difficult for people who are looking for work or have been laid off and want to find new jobs, considering that many companies are still unstable due to Covid-19, so they do not accept new employees. Meanwhile, the resulting economic impacts also vary, starting from the impact on income, economic activity and the impact on expenditure.

\section{The Covid-19 Pandemic in Serang City}

Covid-19, or the Coronavirus, has spread in various regions in Indonesia since the beginning of 2020, including one in Serang City, Banten Province. The city of Serang is the capital of Banten Province, has quite a high number of confirmed cases of Covid19 from March to September 2020. For more details, here are data on confirmed cases that were treated, recovered and died due to Covid-19 from March to September 2020 in Serang City.

19| Journal of Local Government Issues (Logos), 4 (1), March 2021, pp 13- 29 ISSN : 2620-8091 print | 2620-3812 online 
Graph 1. Total Confirmed Covid-19 in Serang City in March-September 2020

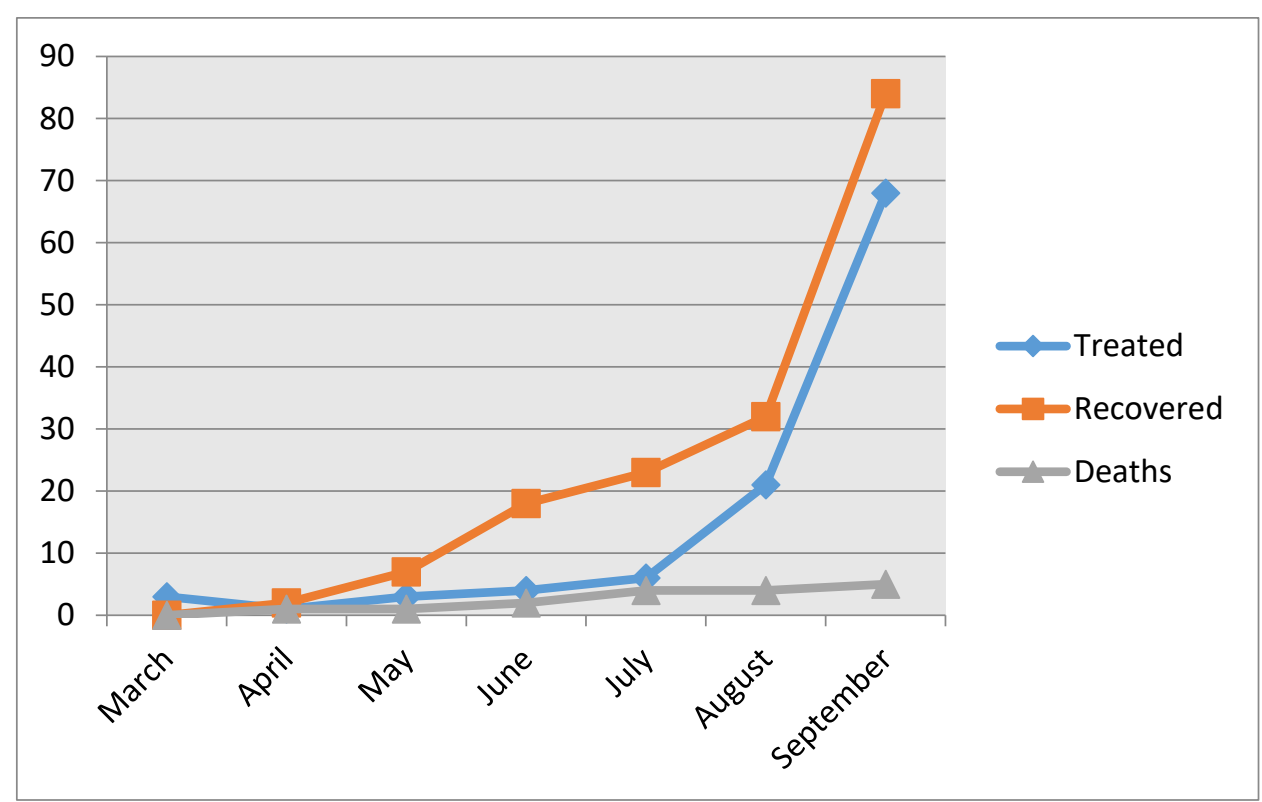

Source: (Serangkota.go.id, 2020)

Based on this graph, it can be seen that from March to September, there has been an increase in the number of confirmed Covid-19. In March, it was confirmed that the number of patients treated was three people. Then in April, it was confirmed that one was treated, two recovered, and one died. In May, three confirmed treated, seven recovered, and one died. In June, four confirmed treated, 18 recovered, and two died. In July, six confirmed treated, 23 recovered, and four death cases. In August, confirmed with a total of 21 treated, 32 recovered, and four died. There was an increase in fluctuation in September, confirmed treatment 68, recovered 84, and five died.

Apart from having an effect on public health in Serang City, Covid-19 also affects the economy of its people, including workers who work in industries or companies in Serang City. According to data from the Serang City Manpower and Transmigration Office (Disnaker), approximately 26 companies or industrial businesses affected by Covid-19, caused these companies or industries to lay off or lay off their employees.

\section{The Economic Impact of Covid-19 on Female Workers in Serang City}

The Covid-19 pandemic has brought many changes to society, both socially and economically. Economic changes have become inevitable since the Covid-19 pandemic occurred in Indonesia's various regions, including Serang, Banten. The employment sector is one of the sectors that are very much affected by Covid-19 pandemic. Both employment in industry, retail, hotels, restaurants did not escape the Covid-19 pandemic.

This study, which focuses on the economic impact on female workers in Serang City, takes the theory from Cohen (Purwanto, 2015) which states that the economic 
impact consists of 3 aspects: the impact on income, the impact on economic activities and the impact on expenditure. These three aspects are essential indicators in the community economy, especially the female workforce, who is the subject of this research.

Overall, Covid-19 has an impact on the workforce in Serang City. Itcan be seen where it is recorded that of the 40,061 workers in Serang City, as many as 132 workers have been sent home and laid off by the company or their place of work (Serang City Manpower and Transmigration Office, 2020a). Although the number of dismissed and laid-off workers was relatively small, this still brought changes to the workforce's socioeconomic conditions, particularly workers.

On the other hand, the Serang City Government's role in addressing the economic impact of Covid-19 is to provide 200,000 rupiahs of basic food social assistance to 50,000 people in Serang City who have been affected by Covid-19 particularly those who have lost their jobs during the pandemic. Massive assistance was provided from May to July 2020. The Serang City Government, through the Department of Industry, Trade and Cooperatives, also provided 500,000 rupiahs stimulus funds to UMKM players whose businesses were affected by Covid-19. The Serang City Manpower and Transmigration Office also acts as a mediator between companies and workers in negotiations to ensure that workers who are laid off and sent home during the pandemic are still entitled to their rights (salary or incentives).

\section{Impact on Income}

Income itself has much understanding from experts. According to (Sadono, 2006) income is the amount of money that the community gets for their work performance in a certain period, weekly, monthly or yearly. Meanwhile, according to (Rahardja \& Manurung, 2010), income is the total income in the form of money or nonmoney by a person or household during a specific period. Meanwhile(Case \& Fair, 2007), state that a person's income comes from three kinds of sources, including: (1) comes from wages or salaries received as employee benefits; (2) derived from property rights, namely capital, land, and so on; and (3) from the government.

This study focuses on income from wages or salaries, which are a source of active income from female workers who work in a company or industrial business. Formal female workers studied in this study came from the retail industry, the food industry and other industrial enterprises in Serang City. These industries include Bella Rossa Cake Parbik, Giant Extra, Alfamart Serang City, PT Bestari Putra Rajawali, Ramayana, Rizky Restaurant "S", and Horison Hotel.

Regarding income, several sources were affected, but some sources were not. Resource persons affected are female workers who have been dismissed and laid off by their workplace. As previously explained, the Covid-19 pandemic caused several industries or industrial businesses to lay off their workers, both female workers and male workers. According to the Manpower and Transmigration Service, of the 6,823 female workers registered, 40 of them were affected and laid off due to Covid-19 (Serang City Manpower and Transmigration Office, 2020b).

This figure shows that not many female workers are affected, either sent away or laid off by their workplace. The number 40 is not tiny, mainly since the data is

21| Journal of Local Government Issues (Logos), 4 (1), March 2021, pp 13- 29 ISSN : 2620-8091 print | 2620-3812 online 
recorded or confirmed by the Manpower and Transmigration Office of Serang City. This data will increase if there are affected female workers who are not registered or confirmed by the Manpower and Transmigration Office of Serang City.

According to the information from one of the informants sent home, she said due to the Covid-19 pandemic; income had decreased drastically. Sartijah disclosed it as the restaurant's resource person, "S" Rizky, who was sent home since the Covid-19 pandemic hit the City of Serang. According to Sartijah, since the Covid-19 pandemic, almost all workers, both women and men at the Rizky "S" restaurant, were sent home without a precise time limit (Sartijah, 2020). Even though they were sent home, Sartijah added that they still irregularly came to work, but only a few days a week. The fixed income that was initially obtained per month turns into weekly income, which is paid according to workdays. Because she only works for a few days, which is around 2-3 days a week, her income is now far from regular income before being sent home (Sartijah, 2020). It affects her daily life continuity, especially when Sartijah has a family, making her life burden increase. This reduced income was experienced by Sartijah and other sources, such as Linda, who was sent home by Hotel Horison and person Windi, whom Bella Rossa Cake Factory also housed. According to Linda, who was sent home for 2-3 months due to the Covid-19 pandemic, she said that she did not receive a salary or wage from her place of work (Linda, 2020). She added employees who returned to work after being laid off were only permanent employees, while not many contract employees returned to work due to the Covid-19 pandemic (Linda, 2020).

This same condition was also experienced by Windi, who was sent home to work due to the Covid-19 pandemic. During her time at home or on vacation, Windi did not get a salary because there was no work production (Windi, 2020). She added that her friends also experienced the same fate where they did not receive income from a salary or wages from their place of work during tdsheir holidays. Furthermore, Windi said that the Covid-19 pandemic had a very significant impact on her, especially on the economic aspect, especially Windi is a workforce who depends on industry for her income, so that when the industrial sector or industrial business begins to fall due to the Covid-19 pandemic, then the workers are the victims.

In addition to the female workers who were sent home, several resource persons who were female workers in this study also experienced layoffs by their workplaces due to the Covid-19 pandemic in Serang City. Eka is one of Ramayana workers who was laid off due to the Covid-19 pandemic in Serang City. According to data from the Serang City Manpower and Transmigration Office, Ramayana is recorded as one of Serang City industries with the most workers laid off due to Covid-19, with 12 employees (Serang City Manpower and Transmigration Office, 2020c).

According to Eka, the layoffs were due to a reduction in employees at her workplace. This workforce reduction is one of the steps that many companies or industries have taken during the current Covid-19 pandemic. It is also in line with (Indonesia, 2003) concerning Manpower which more or less phrase states that a company has the right to terminate employment relations with employees if a company experiences a loss. Even so, workers who are laid off still receive severance pay from their workplace (Eka, 2020).

22| Journal of Local Government Issues (Logos), 4 (1), March 2021, pp 13- 29 ISSN : 2620-8091 print | 2620-3812 online 
Termination of Employment (PHK) also occurred with Sepvi, a worker at PT Bestari Putra Rajawali. The layoffs she experienced were also a result of the Covid-19 pandemic that occurred in Serang City. Quite different from Eka, who was laid off by getting severance pay, Sepvi, who was laid off since March 2020, has not received severance pay from her workplace. Since the Covid-19 pandemic, her workplace has not been conducive and does not support each other among employees (Sepyi, 2020).

One of the company's policies or industry in reducing labor, other than laying off workers, is terminating the contract employees. The termination of the employment relationship with contract workers was carried out by the Alfamart branch of Serang City, where, according to Bella, the company did not extend many contract workers. Bella, an Alfamart employee, added that since the Covid-19 pandemic, the average employee whose contract has not been extended had been a new contract employee. However, contract employees who are not extended their working period still receive severance pay from the company. She added, almost all contract employees whose tenure was not extended were female employees.

From this, it can be seen that the company's policy in reducing the workforce during the Covid-19 pandemic, primarily through layoffs, is a sensitive issue for workers, given the implications it has. For workers, whether male or female, termination of employment (PHK) will eliminate livelihoods that affect the workforce concerned and their families, especially if they are the only work in the family.

For employers, layoffs will result in an obligation for compensation to the workforce concerned. This compensation is usually paid in the form of severance pay to workers, where the amount of severance pay will depend on the length of time the workforce has worked for the company. Based on the decree of the minister of human resources of the Republic of Indonesia number: kep-50 / men / 2000 regarding the settlement of termination of employment and the stipulation of severance pay, employment rewards and compensation in companies, severance pay is a payment in the form of money from employers to workers as a result of the termination employment relationship. The more workers and the longer the workforce, the greater the compensation that employers must prepare (Hernawan, 2016). However, many companies do not pay their workers' severance pay when they terminate their employment, as was the case with Sepvi, who did not receive severance pay from her place of work.

\section{Impact on Economic Activity}

Economic activities related to individuals or groups to acquire goods and services used to meet their daily needs. This activity can be done by exchanging goods or currency either between individuals or groups. The Covid-19 pandemic that has hit various regions in Indonesia, including Serang City, has caused an impact on the community's economic activities, including companies and workers in it. In Serang City itself, the influence of Covid-19 on the activities of both companies and their workforce, including female workers, is quite significant. It can be seen from the number of companies and industries that have reduced their employees, either by being laid off or ending working relationships with contract employees.

23| Journal of Local Government Issues (Logos), 4 (1), March 2021, pp 13- 29 ISSN : 2620-8091 print | 2620-3812 online 
This reduction in employees is undoubtedly one of the company's steps in cutting production, distribution and marketing costs of goods or services. In addition to affecting the economic activities of companies or industries in Serang City, the Covid-19 pandemic also affects the workforce's economic activities, especially women workers who are the subjects of this study.

This pandemic has several implications for female workers in Serang City, such as being laid off, laying off their jobs, and ending work contract extensions for contract employees. For workers who have been dismissed, the Covid-19 pandemic has implications for reducing income due to the incomplete working period, and it is unclear when they will return to work in full. It causes few women workers who then swerve to restore their economy, especially for those who are married as was done by resource person Sartijah, their workplace dismissed employees until an indefinite time. The incomplete work period made Sartijah's income drastically reduced. The wages or salaries received by Sartijah are uncertain, where she is usually paid monthly. However, after being sent home, she only worked a few days a month and was paid a day or week where she worked. Nominal salary is also not like a full-time worker, where she only receives a daily or weekly salary. This condition makes her income significantly reduced because she does not fully work, so that the income she gets is significantly reduced. It makes it difficult for her to make ends meet, especially since Eka is married. Eka's economic problems are even more difficult because her husband, who is an entrepreneur, is also affected by Covid-19, so that both of them experience difficulties in the economy of their household. In overcoming this problem, Sartijah finally joined entrepreneurship to help her husband to meet the needs of her life and her family while waiting to work fully back at her workplace.

Meanwhile, for female workers who were laid off, the most significant impact was the complete loss of income sources. The loss of this income source inevitably causes many workers to return to unemployment, making them look for new jobs to meet their daily needs and families. Unemployment has become a new trend or implication in various countries, including Indonesia, since the Covid-19 pandemic. It is also experienced by the City of Serang, which is faced with many newly unemployed people due to layoffs during the Covid-19 pandemic. It can be seen where during the Covid-19 pandemic, 101 people were sent home, and 36 people were sent home (Disnaker, 2020) . This data itself is recorded data, so there will likely be more cases of workers being dismissed or laid off that are not recorded by the Manpower and Transmigration Office of Serang City. In addition to creating unemployment, the Covid19 pandemic has also made it difficult for many unemployed and new job seekers to find work. There are still many companies or industries that are still unstable, so they have to close the industry or reduce employees due to the Covid-19 pandemic, making it difficult for job seekers, both new and due to layoffs.

The same experienced by sources Sepvi and Eka, who were laid off by their place of work. This layoff made them part of the new unemployed due to the Covid-19 pandemic in Serang City. In the City of Serang itself, it was recorded that in 2020 there were more than unemployment. It is a challenge in itself for workers, both men and women, because not only are they faced with the Covid-19 virus, which threatens their safety and health, but workers also have to deal with their welfare due to loss of jobs or

24| Journal of Local Government Issues (Logos), 4 (1), March 2021, pp 13- 29 ISSN : 2620-8091 print | 2620-3812 online 
sources of livelihood. Support them or their families. Sepvi, as one of the female workers who lost her income as a result of being laid off, also experienced the same fate, where she found it difficult to fulfil her daily needs after being laid off by her workplace. Apart from finding new jobs to continue her life, Sepvi also participates in its pre-employment card program. Apart from that, Sepvi also works in the informal sector of Go Massage. Sepvi revealed that these things (the government's pre-employment card and informal work) helped her make ends meet after being laid off from her workplace.

\section{Impact on Expenditures}

The expenditure that refers to public expenditure, or in this study, is labor expenditure. According to (Bakti, Sumanjaya, \& Hasution, 2010) consumption expenditure is irreversible, meaning that a person's expenditure when income increases differ from spending when income decreases. It can be said that there is a correlation between expenditure and income, where the pattern of spending depends on the income a person earns.

As previously explained, due to the Covid-19 pandemic in Serang City, not a few female workers were affected, whether they were laid off and their work contracts ended. It will not only affect income but will also affect labor expenditure. When the source of income decreases or even disappears, the cycle of spending will be disrupted and will affect the community's welfare.

The same condition was also experienced by female workers who were studied in this study, where some workers who were affected by their work, either because they were laid off or had their work contract ended, mentioned difficulties in fulfilling their daily needs. It will be more difficult for female workers who are married, as experienced by Sartijah. Sartijah, who was sent home by her workplace, said that it was challenging to meet her household's needs after being sent home; significantly, her self-employed husband was also economically affected by Covid-19. Apart from having difficulty fulfilling their daily needs, Sartijah and her husband also have difficulty meeting their children's educational needs who have entered elementary school (Sartijah, 2020). Several other economically affected sources by Covid-19 also mentioned the same thing where the patterns of daily spending, significantly those already married, were disrupted. Not a few of them took advantage of government assistance, such as food assistance and cash assistance during the Covid-19 pandemic, to help with their daily consumption expenditures. Sartijah received food assistance from the Serang City Manpower and Transmigration Service in rice, nuts, oil, instant noodles, masks, and hand sanitisers (Sartijah, 2020). Apart from the government's assistance, not a few workers also receive cash assistance from the company where they work. As stated by Bella, the company where she works provides cash assistance to its employees. However, many workers do not receive assistance from their workplace, as experienced by Windi, who was sent home by her place of work but did not receive assistance from her company.

Apart from both the government and companies' assistance, it is not uncommon for both male and female workers to use severance pay to meet their daily needs until they return to work. It is undoubtedly a challenge for workers, especially those who were laid off during the Covid-19 pandemic, where on the one hand, they

25| Journal of Local Government Issues (Logos), 4 (1), March 2021, pp 13- 29 ISSN : 2620-8091 print | 2620-3812 online 
have to fight against the threat of Covid-19, which threatens their health, but on the other hand, they have to find work to be able to support themselves and their families. Few companies were still unstable either because of decreased turnover so that companies closed because they were no longer able to operate. It will surely make it difficult for workers, both new workers and workers who have been laid off in search of work again.

\section{CONCLUSION}

The Covid-19 pandemic has had a significant impact on society, both from the health side to the economy. Not a few companies have had to reduce their workforce so that they have to close their branches to survive the current situation. Apart from companies, workers are one of the victims who are pretty affected by the Covid-19 pandemic. In addition to facing health threats, the workforce is faced with reducing the workforce for companies affected by the Covid-19 pandemic. Threats such as being dismissed, ending her work period until the heaviest are getting laid off are the real threat to today's workforce. Not a few workers still survive, but workers are also affected by the implications.

In Serang City, the Covid-19 pandemic has had a significant impact on the community's economy, especially its workforce. Not a few of them were sent home, ended their working period and laid off by their workplace. Apart from reducing the workforce's welfare, this implication also increases the trend of unemployment in Serang City. The economic impact that arises starts from the impact on income, the impact on economic activity and the impact on expenditure threatens the affected workforce. In terms of income, for those who are laid off, their work period ends until they are laid off; the real implication is that there is a reduction in the loss of their income source. For those who are married, this implication will be even heavier, considering that they bear not only the burden of their own life but also the burden of other family members. In terms of economic activities, the Covid-19 pandemic has profoundly impacted economic activity, both corporate/industrial economic activity and labor. Production, distribution and public consumption processes are disrupted. Meanwhile, the expenditure side will also be affected, considering that expenditure is correlated with income, so when income is disrupted or changes, the spending pattern will also change. It must receive the government's attention considering that the Covid19 pandemic is still running indefinitely, so attention to the company, especially the affected workforce, is needed so that the community's welfare becomes better during the Covid-19 pandemic.

The researchers draw several suggestions, such as for the Labor Office to reduce and minimize the workforce not to be affected by layoffs due to Covid-19. Next is to assist workers, especially women who are laid off or at home, receive compensation due to Covid-19. On the other hand, for the government and companies to help or open up opportunities for workers, both men and women who have been laid off and the new generation of workers so that it is easier to get jobs during the Covid-19 pandemic. Also, this research expected to add knowledge literature about the impact of Covid-19 on the field of human life, especially on female workers in Serang City. Furthermore, provide an overview of both the government and companies regarding the impact of Covid-19

26| Journal of Local Government Issues (Logos), 4 (1), March 2021, pp 13- 29 ISSN : 2620-8091 print | 2620-3812 online 
on female workers to be used as a recommendation in supporting or encouraging the workforce.

\section{REFERENCES}

Agustina, I. F., \& Octaviani, R. (2017). Analisis Dampak Sosial dan Ekonomi Kebijakan Pengembangan Kawasan Mix Use di Kecamatan Jabon. JKMP (Jurnal Kebijakan dan Manajemen Publik), 4(2), 151-168. https://www.researchgate.net/deref/http\%3A\%2F\%2Fdx.doi.org\%2F10.21070 \%2Fjkmp.v4i2.682

Ashraf, B. N. (2020). Economic Impact of Government Interventions During The COVID19 Pandemic: International Evidence From Financial Markets. Journal of Behavioral and Experimental Finance, 27, 100371. https://dx.doi.org/10.1016\%2Fj.jbef.2020.100371

Azimah, R. N., Khasanah, I. N., Pratama, R., Azizah, Z., Febriantoro, W., \& Purnomo, S. R. S. (2020). Analisis Dampak Covid-19 Terhadap Sosial Ekonomi Pedagang Di Pasar Klaten Dan Wonogiri. EMPATI: Jurnal Ilmu Kesejahteraan Sosial, 9(1), 59-68. https://doi.org/10.15408/empati.v9i1.16485

Bahtiar, R. A., \& Saragih, J. P. (2020). Dampak Covid-19 terhadap perlambatan ekonomi sektor umkm. Jurnal Bidang Ekonomi Dan Kebijakan Publik, 7(6), 19-24.

Bakti, T. D., Sumanjaya, R., \& Hasution, S. H. (2010). Pengatar Ekonomi Makro. Medan: USU Press.

BBCNews. (2020). Covid-19 'terus menyebar', hampir 39 juta kasus terkonfirmasi di 189 negara - bagaimana upaya negara-negara yang masih alami kenaikan kasus?, https://www.bbc.com/indonesia/dunia-54407978.

Block, D. (2017). Political Economy in Applied Linguistics Research. Language Teaching, 50(1), 32-64. https://doi.org/10.1017/S0261444816000288

Budastra, I. K. (2020). Socio-Economic Impacts of Covid-19 and Potential Programs for Mitigation: a Case Study in Lombok Barat District. Jurnal Agrimansion, 20(1), 4857.

Bungin, B. (2009). Penelitian Kualitatif. Jakarta: Kencana Prenada Media Group.

Case, K. E., \& Fair, R. C. (2007). Prinsip-Prinsip Ekonomi. Jakarta:Erlangga.

Chitiga-Mabugu, M., Henseler, M., Mabugu, R., \& Maisonnave, H. (2020). Economic and Distributional Impact of COVID-19: Evidence from Macro-Micro Modelling of the South African Economy. South African Journal of Economics. https://doi.org/10.1111/saje.12275

City, L. O. o. S. (2020). COVID-19, https://disnakertrans.serangkota.go.id/.

Eka. (2020). Interview.

Hanoatubun, S. (2020). Dampak Covid-19 terhadap Prekonomian Indonesia. EduPsyCouns: Journal of Education, Psychology and Counseling, 2(1), 146-153. Retrieved from https://ummaspul.e-journal.id/Edupsycouns/article/view/423

Hernawan, A. (2016). Keberadaan Uang Pesangon Dalam Pemutusan Hubungan Kerja Demi Hukum di Perusahaan Yang Sudah Menyelenggarakan Program Jaminan Pensiun. Kertha Patrika, 38(1). https://doi.org/10.24843/KP.2016.v38.i01.p01

27| Journal of Local Government Issues (Logos), 4 (1), March 2021, pp 13- 29 ISSN : 2620-8091 print | 2620-3812 online 
Indonesia, P. (2003). Undang-Undang No 13 Tahun 2003 tentang Ketenagakerjaan.

Juaningsih, I. N. (2020). Analisis Kebijakan PHK Bagi Para Pekerja Pada Masa Pandemi Covid-19 di Indonesia. Adalah: Buleting Hukum dan Keadilan, 4(1), 189-196. https://doi.org/10.15408/adalah.v4i1.15764

Kusno, F. (2020). Krisis Politik Ekonomi Global Dampak Pandemi Covid-19. Anterior Jurnal, 19(2), 94-102. https://doi.org/10.33084/anterior.v19i2.1495

Linda. (2020). Interview.

Moleong, L. J., \& Surjaman, T. (1991). Metodologi Penelitian Kualitatif. Jakarta: Penerbit PT Remaja Rosdakarya.

Nasution, D. A. D., Erlina, E., \& Muda, I. (2020). Dampak pandemi Covid-19 terhadap perekonomian Indonesia. Jurnal Benefita, 5(2), 212. https://doi.org/10.22216/jbe.v5i2.5313

Office, S. C. L. (2020a). Serang City Manpower and Transmigration Office. https://disnakertrans.serangkota.go.id/

Office, S. C. L. (2020b). Serang City is one of Banten Province areas that is not immune from the impact of the spread of Covid-19, https://disnakertrans.serangkota.go.id/.

Office, S. C. L. (2020c). Serang City Manpower and Transmigration Office. https://disnakertrans.serangkota.go.id/.

Olivia, S., Gibson, J., \& Nasrudin, R. a. (2020). Indonesia in the Time of Covid-19. Bulletin of Indonesian Economic Studies, 56(2), 143-174. https://doi.org/10.1080/00074918.2020.1798581

Pradana, A., Wulandari, A. D., Noorwidhi, B. F., \& Sitinjak, F. (2020). Dampak Pandemi Covid-19 terhadap Ekonomi Nasional dan Perpajakan di Sektor Minyak dan Gas Bumi. Syntax Idea, 2(12), 330999. Retrieved from https://jurnal.syntaxidea.co.id/index.php/syntax-idea/article/view/815

Province, B. (2020). Information on the Distribution of Covid-19, https://www.bantenprov.go.id/index.php

Purwanto, R. D. (2015). Dampak Sosial Ekonomi Dan Lingkungan Penambangan Batubara Ilegal Di Desa Tanjung Lalang Kecamatan Tanjung Agung Kabupaten Muara Enim: Skripsi: Universitas Sriwijaya

Rahardja, P., \& Manurung, M. (2010). Teori Mikroekonomi. Jakarta: LP-FEUI.

Rusiadi, R., Aprilia, A., Adianti, V., \& Verawati, V. (2020). Dampak Covid-19 Terhadap Stabilitas Ekonomi Dunia (Studi 14 Negara Berdampak Paling Parah). Jepa, 5(2), 173-182.

Retrieved from http://jurnal.pancabudi.ac.id/index.php/jepa/article/view/904

Sadono, S. (2006). Ekonomi Pembangunan: Proses, Masalah dan Dasar Kebijakan (Ed II). Jakarta: Kencana.

Saidi, L. O., Adam, P., Rostin, R., Saenong, Z., Balaka, M. Y., Gamsir, G., . . Salwiah, S. (2017). The Effect of Stock Prices and Exchange Rates on Economic Growth in Indonesia. International Journal of Economics and Financial Issues, 7(3), 527.

Sartijah. (2020). Interview.

28| Journal of Local Government Issues (Logos), 4 (1), March 2021, pp 13- 29 ISSN : 2620-8091 print | 2620-3812 online 
Sayuti, R. H., \& Hidayati, S. A. (2020). Dampak Pandemi Covid-19 Terhadap Ekonomi Masyarakat di Nusa Tenggara Barat. RESIPROKAL: Jurnal Riset Sosiologi Progresif Aktual, 2(2), 133-150.

Sepyi. (2020). Interview.

Serang, S. G. T. C.-P. K. (2020). Map of Identification of the Distribution of Covid-19 in Serang City, https://infocorona.serangkota.go.id/.

Setiati, S., \& Azwar, M. K. (2020). COVID-19 and Indonesia. Acta Medica Indonesiana, 52(1), 84-89.

Sugarda, P. P., \& Wicaksono, M. R. (2017). Strengthening Indonesia's Economic Resilience through Regulatory Reforms in Banking, Investment and Competition Law. Journal of Economic \& Management Perspectives, 11(3), 1093-1103.

Suryahadi, A., Al Izzati, R., \& Suryadarma, D. (2020). Estimating the impact of covid-19 on poverty in Indonesia. Bulletin of Indonesian Economic Studies, 56(2), 175-192. https://doi.org/10.1080/00074918.2020.1779390

Ulya, H. N. m. (2020). Alternatif Strategi Penanganan Dampak Ekonomi Covid-19 Pemerintah Daerah Jawa Timur Pada Kawasan Agropolitan. El-Barka: Journal of Islamic Economics and Business, 3(1), 80-109. https://doi.org/10.21154/elbarka.v3i1.2018

Windi. (2020). Interview.

Yamali, F. R., \& Putri, R. N. (2020). Dampak Covid-19 Terhadap Ekonomi Indonesia. Ekonomis: Journal of Economics and Business, 4(2), 384-388. http://dx.doi.org/10.33087/ekonomis.v4i2.179

Zhang, J., Wang, X., Jia, X., Li, J., Hu, K., Chen, G., . . Yu, H. (2020). Risk factors for disease severity, unimprovement, and mortality in COVID-19 patients in Wuhan, China. Clinical Microbiology and Infection, 26(6), 767-772. doi: 10.1016/j.cmi.2020.04.012 